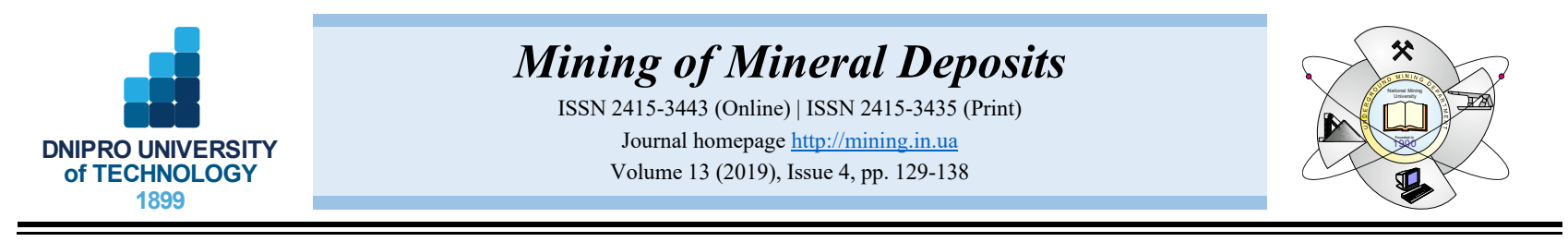

UDC 622.023 .23

https://doi.org/10.33271/mining13.04.129

\title{
ANALYSIS OF OPERATION PARAMETERS OF PARTIAL BACKFILLING IN THE CONTEXT OF SELECTIVE COAL MINING
}

\author{
V. Sotskov ${ }^{1 *}$, N. Dereviahina ${ }^{1}$, L. Malanchuk ${ }^{2}$ \\ ${ }^{1}$ Dnipro University of Technology, Dnipro, Ukraine \\ ${ }^{2}$ National University of Water Management and Environmental Management, Rivne, Ukraine \\ *Corresponding author: e-mail vadimsockov@gmail.com,tel.+380664837512
}

\begin{abstract}
Purpose is to determine factors of effect of mechanical parameters and geometry of packs, constructed using the undercut rocks in the process of selective coal mining, on the state of geomechanical system within a mine workingstope junction during a computational experiment.

Methods. The computational experiments involved finite-element method to simulate three-dimensional analytical area of the geomechanical system. Rock mass was represented by twelve rock layers and a coal seam. In the process of the computations, neighboring rock layers displace freely relative to each other. Stresses and deformations have been calculated within a full-size $300 \times 160 \times 50 \mathrm{~m}$ block involving undisturbed rock mass, a stope and two development workings. Mechanical characteristics of packs were simulated using additional analytical calculations.

Findings. The calculations of a geomechanical system of a mine working-stope junction have helped determine typical areas of the disturbed rock mass identifying a propagation mechanism of the stope roof fall taking into consideration the effect of backfilling parameters. Analysis of stress-strain state (SSS) of the geomechanical system within the stope roof, using the selected cross-sections, made it possible to define conditions of interaction of the rock layers resulting in the roof lowering on the packs.

Originality. The identified regularities of interaction between a stope roof and backfilling components determine optimum conditions to control a stope roof during selective coal mining. It has been substantiated scientifically that consideration of longitudinal horizontal stresses to identify optimum backfilling parameters makes it possible to define unambiguously both a type, and geometry of protection schemes for the mined-out area of a stope in terms of different strength parameters and geometrical parameters of the disturbed rock mass.

Practical implications. The results have helped determine a mechanism of a stope advance velocity as well as a type and geometry of the packs being constructed. The abovementioned makes it possible to minimize expenditures for internal logistics; to cheapen prime cost of mining; and to improve safety of stope miners.
\end{abstract}

Keywords: rock mass, stope, stress-strain state, support section, partial backfilling, pack

\section{INTRODUCTION}

\subsection{Statement of the problem}

Selective coal mining makes it possible to solve a number of problems arising during stoping within coal seams which thickness is less than a meter (Glamheden \& Hökmark, 2010; Fomychov, 2012; Kovalevs'ka, Symanovych, \& Fomychov, 2013). However, the key initial problem of the method is significant amount of rock, being undercut, which was planned to hoist to the surface originally (Dayang, 2013; Wang \& Tu, 2015; Hu, Li, Hu, Zhou, \& Yue, 2018; Li et al., 2018). Nevertheless, the development of the mined-out area backfilling with the use of the undercut rock has helped solve the problem.
Boundaries of the method as well as its efficiency concerning the protection of mine workings determines amount of rock, being available for backfilling. Strictly speaking, ratio between empty space of the mined-out area, and amount of rock, being undercut, is meant (Miao, Zhang, \& Feng, 2008; Zhang et al., 2011; Zhou, Jiang, \& Zhang, 2013; Zhang, Jiang, Deng, \& Ju, 2014).

The ratio defines a capability to select one of the backfilling alternatives - either complete backfilling or packing. Complete backfilling is possible if only height of rocks, being undercut, is significant. The restriction is senseless for packs since their formation provides means for selecting distances between them (Bondarenko, Kharin, Antoshchenko, \& Gasyuk, 2013; Sotskov \&

(C) 2019. V. Sotskov, N. Dereviahina, L. Malanchuk. Published by the Dnipro University of Technology on behalf of Mining of Mineral Deposits.

This is an Open Access article distributed under the terms of the Creative Commons Attribution License (http://creativecommons.org/licenses/by/4.0/),

which permits unrestricted reuse, distribution, and reproduction in any medium, provided the original work is properly cited. 
Saleev, 2013) considered filtration processes (Chui, Moshynskyi, Martyniuk, \& Stepanchenko, 2018; Bomba, 2018). The geometrical factor is not the only one effecting a format of the mined-out backfilling. In several cases, mechanical characteristic of rocks needs optimization of the backfilling method (Shcherbakov, Tymchenko, Buhrym, \& Klymenko, 2019). It depends upon the aim to meet the requirements for the conjugated stope and mine working. Backfilling parameters may become the decisive factor effecting operation of the supports of mine workings, and deformation dynamics of their boundaries (Gornostayev, Crocket, Mochalov, \& Laajoki, 1999; Khalymendyk \& Baryshnikov, 2018).

\subsection{Analysis of previous studies}

Analysis of the available backfilling methods with the use of modern powered complexes has shown that pneumatic techniques and mechanical techniques are the most popular in the context of the industry (Fahey, Helinski, \& Fourie, 2009; Haibin \& Zhenling, 2010; El Mkadmi, Aubertin, \& Li, 2014). Solving certain engineering problems (i.e. rock pressure control within stopes; mining of coal reserves, left under the protected structures; maintenancefree support of mine workings; and leaving of rock from undercuts in stopes and shortwalls) involve various operation schedules aimed at rock placement within the minedout area of longwalls with the help of pneumatic facilities, throwers, scraper equipment, and stowage conveyors (Reynolds, 2002; Powell, 2003; Cao, Nemcik, \& Aziz, 2010; Fan, Zhang, \& Wang, 2014). For instance, paper (Aziz \& Jalaifar, 2005) analysis of rock mass mining and loading has shown that if a stope operates according to a one-way schedule (i.e. in two passes of a coal shearer), up to $8 \%$ of the broken rock mass or rock turns out to be on the floor; if a shuttle procedure (i.e. one pass of a coal shearer) is applied then the figure increases up to $32 \%$ along with ash content of the coal being mined.

\subsection{Geology of the site under analysis}

The research has been carried out relying upon mining and geological conditions of longwall 4206 development of $\mathrm{C}_{4}{ }^{2}$ seam in Samarska mine (DTEK Pavlohradvuhillia PJSC). The coal seam $\mathrm{C}_{4}{ }^{2}$ is of a simple structure; its thickness is $0.69-0.81 \mathrm{~m}$; and geological thickness is $0.74 \mathrm{~m}$. Its hypsometry is undulating one; and inclination angle is $1-5^{\circ}$. Coal grade is DH. Sandstone with up to $0.8 \mathrm{~m}$ thickness is immediate roof of the seam; rock-hardness ratio is $f=2-4$; rock category is $\mathrm{B} 1-\mathrm{B} 3$; argillite thickness is $0-2.5 \mathrm{~m}$; rock category is $\mathrm{B} 1-\mathrm{B} 3$; and rock-hardness ratio is $f=1-3$.

Immediate roof is represented by argillite, aleurite, and sandstone with up to $20 \mathrm{~m}$ thickness; rock-hardness ratio is $f=2-4$; and rock category is $\mathrm{A} 1-\mathrm{A} 2$. Initial caving of the main roof is expected every other $20-30 \mathrm{~m}$; further caving of the main roof is expected every other $20-35 \mathrm{~m}$. Lumpy argillite with $1 \mathrm{~m}$ thickness is the seam floor; rock-hardness ratio is $f=1$; rock category is $\mathrm{P} 1-\mathrm{P} 2$; operating depth is $150-180 \mathrm{~m}$. Longwall length is $250 \mathrm{~m}$; working area length is $1568 \mathrm{~m}$. Roof is controlled by the complete caving; mining method is up-dip pillar technique.

The longwall watering will be connected with coal seam $\mathrm{C}_{4}{ }^{2}$, coal shed, and sandstone within the main roof, and immediate roof. As for the covering deposits, the prognosticated water inflow is up to $10 \mathrm{~m}^{3} / \mathrm{h}$ (it may achieve $25 \mathrm{~m}^{3} / \mathrm{h}$ recorded while driving a haulage drift of $\mathrm{C}_{4}^{2}$ seam).

\section{METHODS}

In the context of complete backfilling, take elasticity modulus $E=50 \mathrm{MPa}$ and fragmentation degree $K_{p}=1.45$ for the rocks being undermined relying upon the experimental data represented in papers (Shashenko, Gapieiev, \& Solodyankin, 2009; Grigoriev, Tereschuk, \& Tokar, 2015; Małkowski, Ostrowski, \& Brodny, 2018). Naturally, the taken value cannot be absolute ones since fragmentation degree of rock being undermined depends upon its mechanical strength and coal mining method. In turn, residual deformation characteristics of rock, used for backfilling, are determined basing upon its fragmentation geometry. Thus, the selected parameters of the undermined rocks are both average and typical for the considered coal mining method as well as for mechanical characteristics of rocks in Western Donbas mines.

Consideration of the efficiency of different alternatives for the worked-out area backfilling will involve three variants of rocks being undermined, i.e. 0.5, 0.6, and $0.7 \mathrm{~m}$. Rock amount after fragmentation should be calculated for each of the variants. Perform the calculation using the formula:

$V_{p}=K_{p} \cdot V$,

where:

$V_{p}-$ an amount of the rock being undermined resulting from fragmentation;

$V$ - an amount of rock being undermined before it was extracted.

Consequently, in terms of the selected engineering values, equivalent of linear dimensions throughout the height of the rocks being undermined will become $0.73 \mathrm{~m}$ for $0.5 \mathrm{~m}$; $0.87 \mathrm{~m}$ for $0.6 \mathrm{~m}$; and $1.02 \mathrm{~m}$ for $0.7 \mathrm{~m}$ before fragmentation and after it respectively. Further, the obtained values will be applied for computational experiment to determine stress-strain state of a geomechanical system of a stope-mine working junction. As for the packs for the mined-out area backfilling, select elasticity modulus $E=500 \mathrm{MPa}$, and fragmentation degree $K_{p}=1.2$. Use expression (1) again to obtain following equivalent of linear dimensions through the height of the rocks being undermined before fragmentation and after it taking into consideration pneumatic compaction: $0.6 \mathrm{~m}$ for $0.5 \mathrm{~m} ; 0.72 \mathrm{~m}$ for $0.6 \mathrm{~m}$; and $0.84 \mathrm{~m}$ for $0.7 \mathrm{~m}$.

Determine technological parameters of packs in terms of different height values relying upon the obtained data. Following expression is the basis for stage one calculation:

$V_{b}=b \cdot h \cdot l$,

where:

$V_{b}$ - an amount of the mined out area per one pass of a coal shearer;

$b$ and $l-$ the height of the longwall, and its length respectively;

$h$ - web width of the coal shearer effector.

If $b=1 \mathrm{~m}, l=250 \mathrm{~m}$, and $h=0.8 \mathrm{~m}$, we obtain: 
$V_{b}=200 \mathrm{~m}^{3}$,

If the equivalent dimensions, obtained for rock fragmentation, are applied as $b$ values, then we obtain volumes which can be used for the mined-out area backfilling.

The following results for complete backfilling values:

$V_{0.5}=146 \mathrm{~m}^{3}$;

$V_{0.6}=174 \mathrm{~m}^{3}$;

$V_{0.7}=204 \mathrm{~m}^{3}$.

Taking into consideration pneumatic compaction, we have the following for packs:

$$
\begin{aligned}
& V_{0.5 u}=120 \mathrm{~m}^{3} ; \\
& V_{0.6 u}=144 \mathrm{~m}^{3} ; \\
& V_{0.7 u}=168 \mathrm{~m}^{3} .
\end{aligned}
$$

The values, resulted from equation (5) will be applied to determine geometrical characteristics of packs while the mined-out area backfilling. Calculate residual volume of the mined-out area not stowed with packs using the formula:

$$
\begin{aligned}
& V_{0.5 e}=V_{b}-V_{0.5 u}=80 \mathrm{~m}^{3} ; \\
& V_{0.6 e}=V_{b}-V_{0.6 u}=56 \mathrm{~m}^{3} ; \\
& V_{0.7 e}=V_{b}-V_{0.7 u}=32 \mathrm{~m}^{3} .
\end{aligned}
$$

Taking into consideration the fact that during one pass of a coal shearer, $0.8 \mathrm{~m}^{3}$ of the mined-out area falls within a running meter, we obtain total length of the nonpacked area within the considered mine working: $100 \mathrm{~m}$ for $V_{0.5 e}-70 \mathrm{~m}$ for $V_{0.6 e}$; and $40 \mathrm{~m}$ for $V_{0.7 e}$. Thereafter, pack width will be $7.5 \mathrm{~m}$ for $V_{0.5 e}$ and distance between neighbouring packs will be $5 \mathrm{~m}$; pack width will be $9 \mathrm{~m}$ for $V_{0.6 e}$ and distance between neighbouring packs will be $3.5 \mathrm{~m}$; and the width will be $10.5 \mathrm{~m}$ for $V_{0.7 e}$ when the distance is $2 \mathrm{~m}$.

Hence, basic technological parameters have been formed determining both limits and feasibility to implement different backfilling methods depending upon mechanical characteristics of rock mass, and a stope-mine working junction geometry. The described parameters for a stope backfilling provide possibility to select optimum geometric values of packs in terms of coal mining method, stope length, and height of rocks being undermined.

\section{RESULTS AND DISCUSSION}

\subsection{Effect of technological parameters of packs and complete backfilling}

Deformation processes of a mine working boundary progress due to its roof and floor displacement. That depends upon significant length of a stope along with low height of the mine working. Roof lowering and floor lifting follow the principle of plane-parallel displacements oriented perpendicularly to a gravity axis (Bondarenko, Kovalevs'ka, \& Fomychov, 2012; Babets, Sdvyzhkova, Larionov, \& Tereshchuk, 2017; Lozynskyi, Saik, Petlovanyi, Sai, \& Malanchuk, 2018). In such a case, vertical stresses become the prevailing efforts balancing the geomechanical system. The stresses also form effect on other components of stress-strain state of rock mass within areas adjoining a stope and a mine working (Fomichov, Sotskov, \& Malykhin, 2014; Fomichov, Sotskov, Pochepov, \& Mamaikin, 2018).

Rapid deformation growth, caused by vertical stresses within a mine working roof, results in a high fracturing rate. Origination of the main cracks prevents from dissipation of the accumulated energy of rock deformation thus factoring into the uncontrolled braking of boundary rock layers (Sotskov \& Gusev, 2014; Malanchuk, et al., 2019). Consequently, a stope advance results in the increased rock pressure within the area of the powered support location; roof rocks of the mine workings experience their softening which gives rise to its operational performance degradation (Sdvizhkova, Babets, \& Smirnov, 2014). Thus, to understand processes, taking place during deformation of boundary of the conjugated mine workings it is necessary to analyze a distribution pattern of vertical stress distribution within rock mass.

Start consideration of volumetric epures of vertical stresses from the comparison of effect of technological parameters of packs within the mined-out area of a stope on the SSS within a mine working wall. Figure 1 represents a stress pattern within cross section of rock mass located at $0.5 \mathrm{~m}$ distance from a stope-mine working junction plane. In its central share, a model of the powered support is placed. The model is of a parallelepiped form; its height is a meter and its width is 5.5 meters. The undisturbed rock mass is to the left of the model; a stope with packing or complete backfilling it to the right. Such a location is true for each similar epure below.

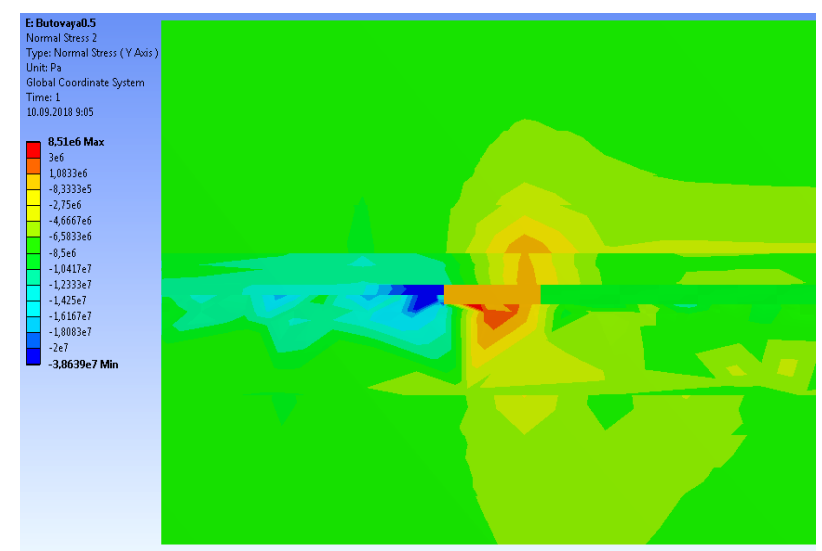

Figure 1. Vertical stresses within a cross section at $0.5 \mathrm{~m}$ distance from a stope during packing when height of rocks being undermined is $0.5 \mathrm{~m}$

Total analysis of epures, represented in Figure 1, demonstrated the following:

- more than $90 \%$ of the analytical model in under the effect of compressive stresses which is true for the elastic problem approach corresponding to vertical stress application to upper edge of the model and its lower edge;

- maximum compressive stresses are in front of the stope plane towards the undisturbed rock mass which corresponds to the practices of stress variation measurements under full-scale conditions; 
- formation of tensile stress areas depends upon the effect of the powered support model upon the adjoining rock layers which is confirmed by actual conditions of its operation;

- vertical stresses within the mine working roof are more than stresses within its floor which is supported by stope operation in Western Donbas mines.

Effect of tensile stresses upon the stope is localized within the area adjoining the powered support. As a result, horizontal gradient of vertical stresses within the stope roof is equal to zero.

Hence, packing, applied to provide satisfactory operational characteristics of a mine working-stope junction, helps achieve uniform vertical load distribution on the support and on the protective structures of a mine working which may cut the likelihood of the main fracturing, and decrease dimensions of boundary rock mass softening. On the other hand, changes in the height of rocks being undermined cannot cause changes in the powered support operation mode, and cannot effect stress distribution within the undisturbed rock mass behind the stope face.

Epures in Figure 2 involve a number of characteristics which are not typical for calculations with packing. The key difference of the epure is stress change in the stope roof in the area of rock mass adjoining the powered support model.

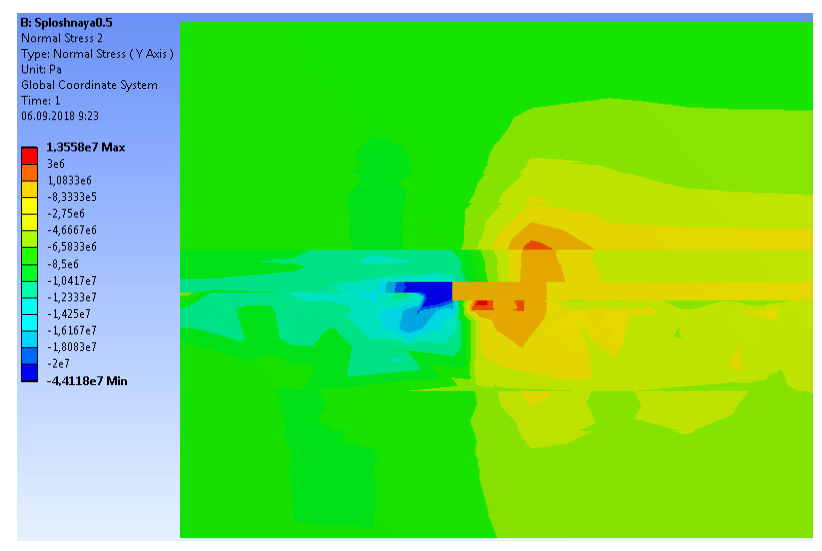

Figure 2. Vertical stresses in a cross section at $0.5 \mathrm{~m}$ distance from the mine working in the context of complete backfilling when the height of rock being undermined is $0.5 \mathrm{~m}$

Effect of the powered support on the stress distribution within the mine working roof includes $10-15 \mathrm{~m}$ towards the mined out area; if maximum stresses increase, $21-24 \%$ growth is observed as for the calculations concerning packs. It means that complete backfilling helps involves greater rock amount into the process of roof stabilization. However, the characteristic is cancelled out completely if vertical stresses increase.

Hence, potential energy of roof deformation for calculation alternatives, represented in Figure 1 and 2, is accumulated similarly in terms of the quantitative index. Through the changes in the value and geometry of vertical stress gradient, taking place in the process of complete backfilling, distance between the main cracks increases relative to packs resulting in the formation of larger rock blocks (Sotskov, Russkikh, \& Astafiev, 2015; Nehrii, Nehrii, \& Piskurska, 2018).
The findings help conclude the following: in terms of packing and complete backfilling, behaviour of boundary rock mass is described by means of linear regularities, and exponential regularities stipulating increase in the maximum vertical stress difference depending upon the increase in the height of rocks being undermined.

If longwall length is $250 \mathrm{~m}$ then rock mass area originates at $120 \mathrm{~m}$ distance from a mine working-stope junction. Factors of technogenic impact on the rock mass stress-strain state are minimized to the utmost within the area. Hence, the area is applied to analyze stress distribution taking into consideration three typical axial sections of packs. Stress distribution within roof, represented in Figure $3 \mathrm{a}$, shows that it resists uniformly the displacement to the stope cavity along the full length; the value resistance is $17 \%$ less to compare with floor resistance. Stresses are distributed uniformly within the stope floor; stress value variations are $9-12 \%$ of maximum ones. The pack model takes greater vertical stresses to compare with those taken by surrounding rocks; moreover, the stress distribution is of regular nature as well.

(a)

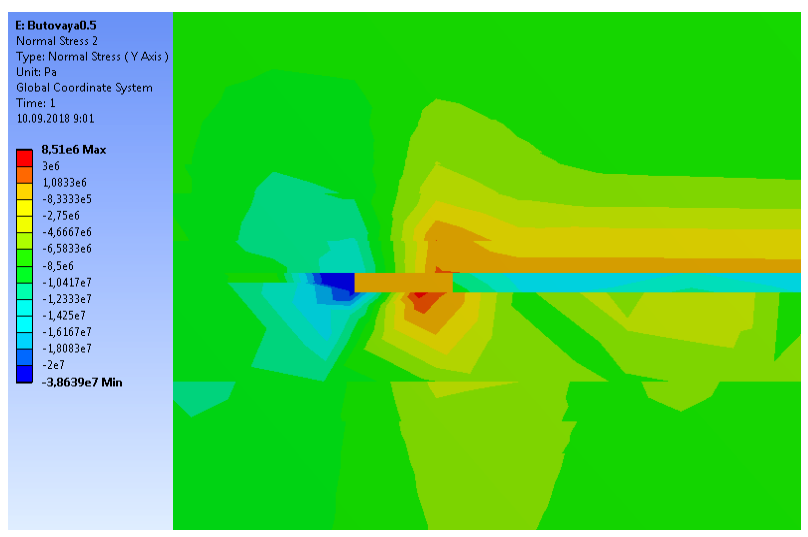

(b)

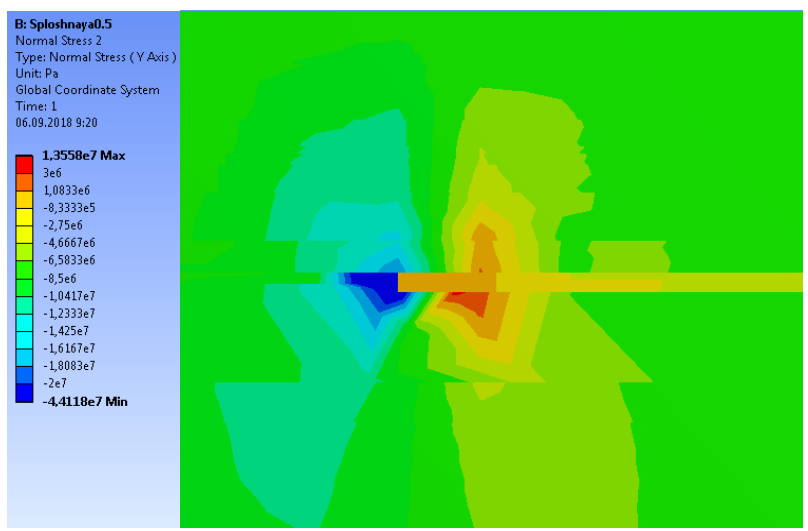

Figure 3. Vertical stresses within central cross section of a stope when the height of rocks being undermined is $0.5 \mathrm{~m}$ in terms of: (a) packing; and (b) complete backfilling

Thus, the pack acts as a compensative damper in the process of effort transfer from roof to floor. Minimum vertical stresses within a pack are placed at the beginning over $L_{p}=2.5 \mathrm{~m}$ from the powered support model edge. $L_{p}$ value is the determining parameter to select a stope face advance rate during packing implementation. 
In the context of complete backfilling, the disintegrated rock is placed continuously along a stope which results in the natural pack compacting. Formation of packs needs certain interval, determined relying upon mechanical conditions of disintegration, during which the placed rock takes load-bearing characteristics. The characteristics can be formed naturally if only minimum external loads are available which do not provoke dynamic phenomena within the packs being formed. Hence:

$$
v_{s a}=L_{p} \cdot t_{s p} \mathrm{~m}^{3}
$$

where:

$v_{s a}$ - a stope advance rate;

$L_{p}$ - a length of a pack area rejecting rock pressure;

$t_{s p}$ - a stabilization period of the pack meter.

The calculations have shown that maximum $L_{p}$ value corresponds to $0.6 \mathrm{~m}$ height of rocks being undermined, i.e. it is $3.4 \mathrm{~m}$; if the height is $0.7 \mathrm{~m}$, the minimum value is obtained, i.e. $1.2 \mathrm{~m}$. In essence, the parameter has nonlinear characteristic too.

As a result, optimum stope advance rate determination in terms of load-carrying capacity of a pack takes place basing on the results of full-scale experiments. The development of physicomathematical model of the process should involve further research which trend and amount are beyond the range of the subjects being considered.

Comparative analysis of the epures has shown that in both cases, area of high compressive stresses has similar geometric configuration of the gradient value. The stresses, experienced by roof rock, shown in Figure 3a, are $8 \%$ less to compare with those in Figure 3b. If complete backfilling is applied, no floor stress variations along the stope cross section are observed.

On the whole, rock mass is loaded uniformly when complete backfilling is used; however, compressive stress concentration is higher within the undisturbed rock mass to compare with packing. Hence, qualitative distinctions as for the stress distribution among epures, represented in Figure $3 \mathrm{a}$ and $3 \mathrm{~b}$, are as follows:

- in terms of calculation alternative one, local stress distribution within the undisturbed rock mass as well as within the stope floor are $22 \%$ less to compare with calculation alternative two;

- stress taking by a material on the pack wall is $18 \%$ higher to compare with complete backfilling.

The abovementioned means that dynamic phenomena arise within the packs along the whole length of the stope. High rock pressure effect results in the loose mass compaction; depending upon loading conditions, it may factor into the geomechanical system stabilization or into active progress of the main cracks within the stope immediate roof. Under the conditions, determination of stress-strain state development of the geomechanical system is an individual problem solved using multiparameter system to analyze a state of complex structured enclosing rock mass (Vladyko, Kononenko, \& Khomenko, 2012). The key distinctions are observed from the mined-out area of the stope. Vertical stress gradient decreases within the immediate roof of the mine working, and within its floor. Pack demonstrates minor increase in compressive stresses. Hence, stabilization process of the pack material state depends upon the decreased pressure effect on the backfilling components.

During complete backfilling, two areas of high compressive stresses and high tensile stresses originated around the powered support model. To compare with computational alternatives concerning use of packs, effect of the areas is oriented true vertically involving almost each rock layer of the analytical model. Consequently, the load, taken by the support, increases if alternate stresses are available within the neighbouring rock mass. As for the $0.5 \mathrm{~m}$ height of rocks being undermined, increase in vertical stresses achieved $22 \%$ and areas of high stresses increased by $35 \%$.

Analysis of vertical stress distribution in the context of packing (Fig. 3a) and in the context of complete backfilling (Fig. 3b) demonstrates similar patterns in the immediate roof of the stope, and in its floor. Thus, backfilling efficiency is comparable for the two variants if the undermined rock height is $0.6 \mathrm{~m}$. However, packing is more preferable technique if high compressive pressure area within the undisturbed rock mass over the powered support model is taken into consideration.

To compare with other computational alternatives, the epures are characterized by the least values of high stress areas in the context of the both types of the backfilling methods. On the whole, the pattern of vertical stress distribution corresponds to the epures; nevertheless, maximum stress values are $12 \%$ less as for the calculation one (Fig. 3a) when packing is used, and $6 \%$ less when complete backfilling is applied (Fig. 3b). Therefore, if the maximum considered height of rocks being undermined is $0.7 \mathrm{~m}$ then within the area, adjoining the powered support model, the geomechanical system has brought to equilibrium in the best way.

In the context of complete backfilling, the area of high compressive stresses for 0.6 and $0.7 \mathrm{~m}$ heights of rocks being undermined is similar while differing qualitatively from $0.5 \mathrm{~m}$ variant. 1.5 times increase of compressive stresses within immediate roof over the powered support is typical for the calculation alternatives. It means that the increased amount of rocks being undermined during complete backfilling doesn't factor into changes in the stress-strain state of the rock mass. However, similar stable pressure effect on the powered support takes place in the process of calculations for $0.5 \mathrm{~m}$ height of rocks being undermined which means incremental probability of rigid setting of the powered support legs.

The following has been concluded relying upon the analysis of vertical stress epures:

- in the context of the considered mining and geological conditions, performance of a mine working is better while packing than while complete backfilling;

- packing results in the fact that vertical stresses within the stope roof and floor vary orderly along the stope advance axis, and across it;

- height of rocks being undermined governs the changes in the immediate roof of stope during packing and during complete backfilling but in different ways;

- in the context of packing, vertical stress distribution along a stope face within the undisturbed rock mass is of more uniform nature to compare with complete backfilling; it is $12-16 \%$ less in terms of absolute values. 


\subsection{Analysis of stress distribution within rock mass stratification planes along a stope advance}

Under the conditions of high structuredness of rock mass, enclosing a stope, horizontal stresses are among the basic factors determining parameters of the controlled roof caving in the process of the stope advance. Changes in the stress values along the stope face, and across it define both shape and time of destructive wave within rock layers, which form a roof of the considered geomechanical system.

Following analysis is a comparison of characteristics of horizontal stresses in the context of different sections of one and the same calculation (Fig. $4 a$ and 4b). Determine the impact of the backfilling methods on the state of the fine-grained rock mass within a roof of a geomechanical system of a stope and a mine working. Vertical plane, oriented in parallel with the stope face and placed over the powered support is common for the epures. Analytical stress alternation from compressive to tensile ones takes place within the plane. Parameters of the plane, its dimensions, and geometrical changes help identify proportions of rock mass being involved in the process of the stope roof deformation.

(a)

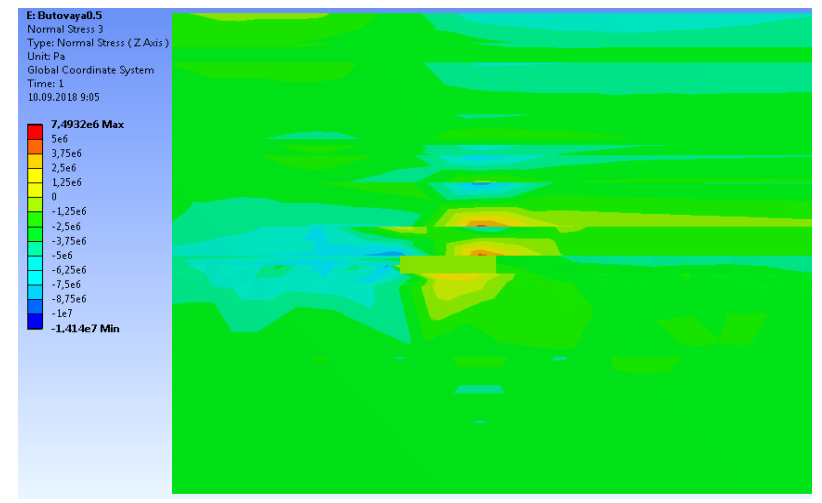

(b)

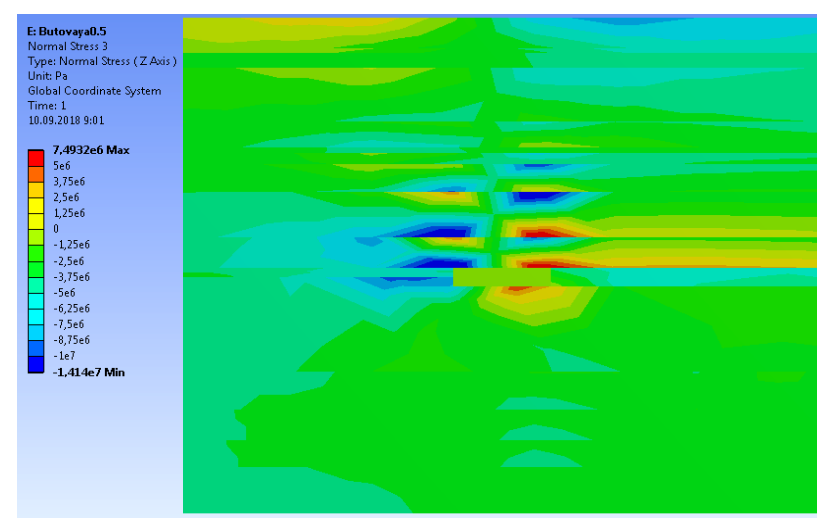

Figure 4. Cross section of horizontal stresses during packing when height of rocks being undermined is $0.5 \mathrm{~m}$ : (a) at $0.5 \mathrm{~m}$ distance from the mine working; and (b) in the central diametric plane

Comparison of Figure $4 \mathrm{a}$ and $4 \mathrm{~b}$ helps understand that height of alternative stress plane experience its $27 \%$ increase from the mine working edge to the stope central share. Local areas of high compressive stresses and tensile stresses also increase towards the stope central share; the increase is 2 to $53 \%$ in absolute values and changes in geometry of the areas achieve $145 \%$. However, only vertical increase is observed.

Relying upon the results, it is possible to conclude that increase in the alternating plane height results in the increase of horizontal stresses within a local roof area of a mine working adjoining the powered support model being indicative of horizontal displacement intensification with distancing from the stope edge. The abovementioned results in the formation of ovoid-like front of progress of the main cracks directed across the stope.

It is seen in Figure $4 \mathrm{~b}$ that to compare with epures, represented in Figure 4a, increase in horizontal stresses takes place in the undisturbed rock mass, and in the stope floor. Thus, growth of shear deformations occurs since they originate when rocks converge into the stope cavity. If effect of the undisturbed rock mass within walls of mine workings helps decrease horizontal stress level in the neighbourhood of the mine working, the distance is neutralized distance is considerable. Hence, the lesser distance between stress distribution in sections, represented in Figure $4 a$ and $4 b$ is, the more stable the roof of the considered geomechanical system becomes. Relying upon the conclusion, formulate rule one: optimum backfilling conditions are possible if only deviations in the alternating plane are minimal along the whole length of a stope.

Comparative analysis of epures, demonstrated in Figure $5 \mathrm{a}$ and $5 \mathrm{~b}$, has shown that $12 \%$ stress growth within the undisturbed rock mass in front of the stope face results in the increased load on backfilling (i.e. 7\%). Hence, the two factors are interconnected for Ukrainian mines; moreover, their connection makes it possible to evaluate firmness of the design bearing capability of protective measures relative to the original rock mass. Thus, we obtain rule two: decrease in horizontal stress difference within the disturbed rock mass in the context of packing or complete backfilling demonstrates growth of load-bearing capacity of a protective structure to compare with other alternatives.

For the calculation option, intensity of horizontal stress changes along a stope face is 1.3 times higher than in terms of packing. Height of alternating stress plane achieves upper boundaries of rock layers of the analytical model meaning the deteriorated conditions of rock layer state under the considered geomechanical system in the context of complete backfilling.

Stresses within a central cross share of a stope immediate roof form a pattern being close to the formation of a vertical section over the powered support legs. Within the central share of the stope, the powered support legs resist loads, increased by $40 \%$, directed towards the mined-out area; i.e. despite complete backfilling, deformation processes intensify within the mine working roof. The processes are aimed at separation of a certain immediate roof share along the stope face. It turns out that stress-strain state of the rock mass is less stable for complete backfilling to compare with packing; however, the state cannot be considered as that corresponding to rock failure criteria with the formation of the main cracks.

Fast growth of horizontal stress value in the neighbourhood of the mine working and in the central share of the stope is observed when complete backfilling is applied and height of rocks being undermined achieves $0.6 \mathrm{~m}$ nature of high stress area formation remains invariable; however, the area dimensions increase their $17 \%$ increase. 
(a)

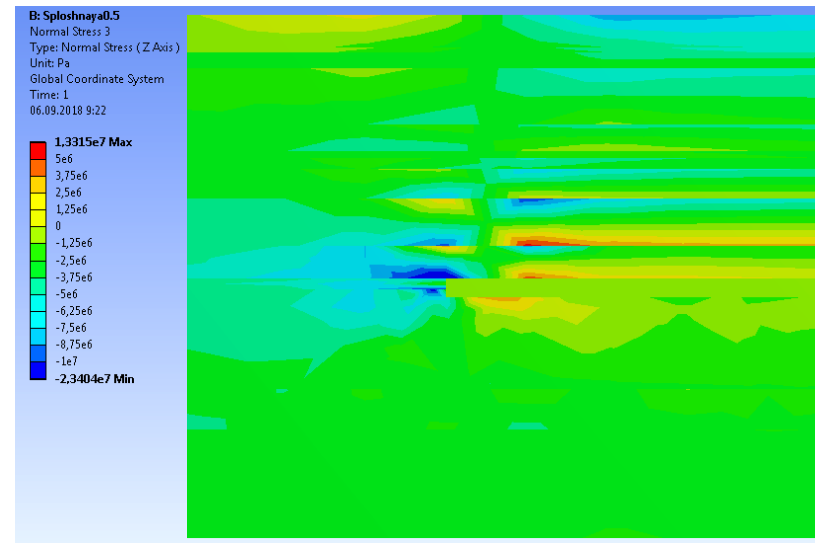

(b)

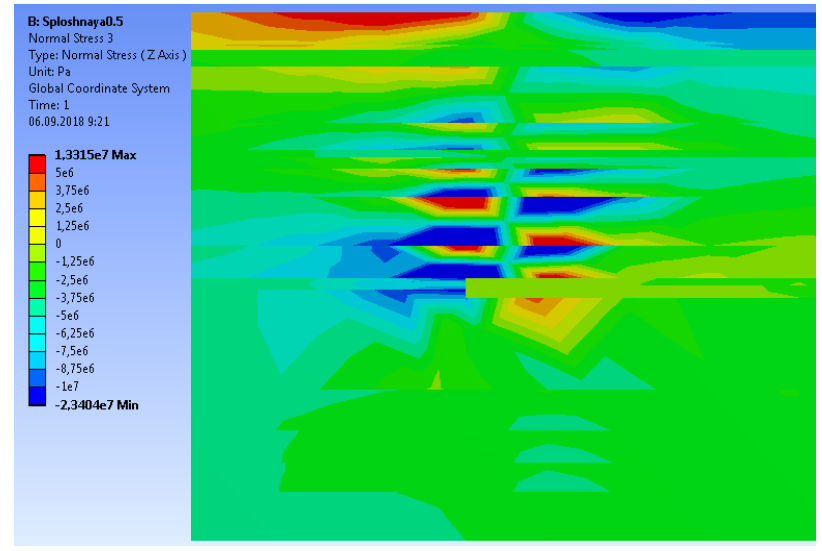

Figure 5. Cross sections of horizontal stresses in the process of complete backfilling if height of the rocks being undermined is $0.5 \mathrm{~m}$ : (a) at $0.5 \mathrm{~m}$ distance from the mine working; and (b) in the central diametric plane

In this context, in the neighbourhood of the mine working, average increase in tensile stresses is $14 \%$ and average increase in compression stresses is $9 \%$ indicating sharp increment of load on the support, and on protective structures of the mine working which may result in the accelerated process of rock heaving, and arch lowering (Khomenko, Sudakov, Malanchuk, \& Malanchuk, 2017). Moreover, height of alternating stress plane remains constants for each calculation alternative. It also means that there are no fundamental changes in the process of formation of areas of ultimate state of rocks within a mine working roof. However, constant growth of horizontal stresses shows that the increased height of rocks being undermined enhances likelihood of roof rock softening right over the powered support section. The dependence is nonlinear and increase of the rocks being undermined results in the decreased growth of maximum stresses.

Since horizontal stresses within the stope roof are of maximum values in the context of complete backfilling, it is required to analyze specific features of their distribution in the immediate roof. In terms of the mining and geological conditions, immediate roof of the stope consists of three rock layers enumerated in the analytical model from one to three starting from the coal seam being mined.

\subsection{Comparative analysis of the findings}

Assume intersection of a stope face with its central vertical section as the analysis area. Consider separately and comparatively maximum compressive stresses (Fig. 6) and tensile stresses (Fig. 7) arising in certain rock layers.

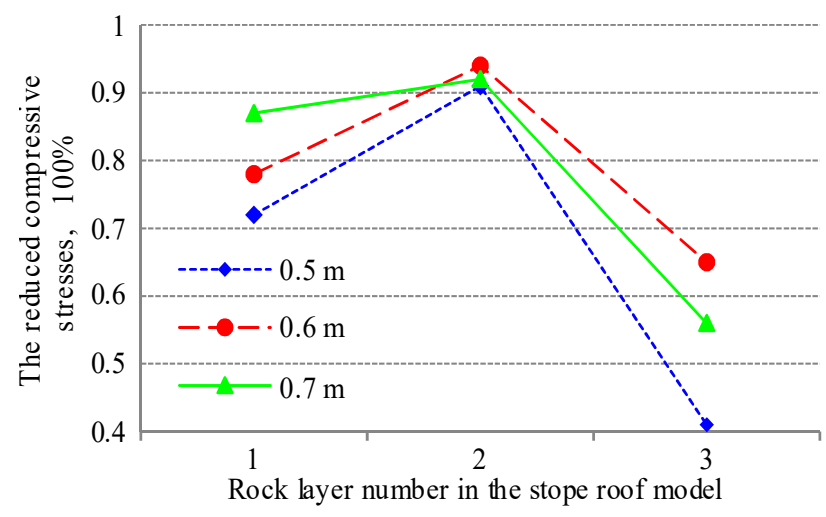

Figure 6. Changes in the reduced maximum compressive horizontal stresses in terms of rock layers of a stope face in the central share of a mine working in the context of complete backfilling with the varying height of rocks being undermined

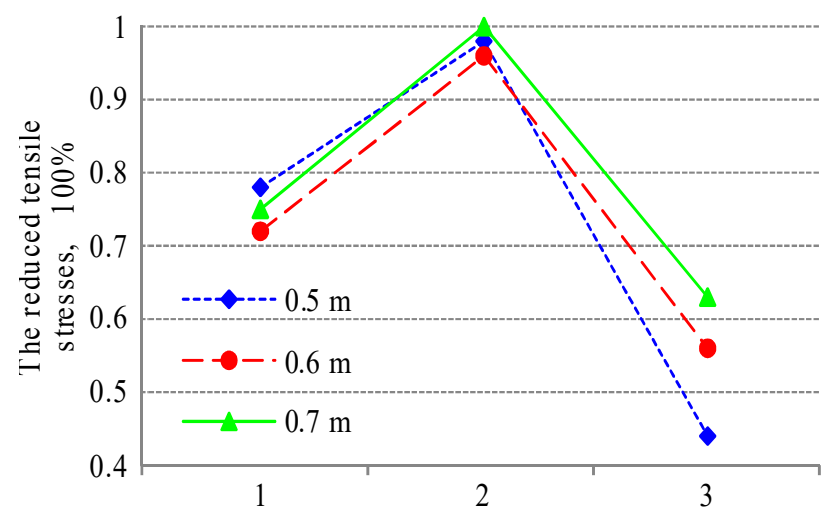

Figure 7. Changes in the reduced maximum tensile horizontal stresses vertically on the stope face in the central share of the stope in the context of complete backfilling with the varying height of rocks being undermined

Qualitatively, the graphs, represented in Figure 7, have no significant differences. Maximum stresses for each calculation alternative are experienced by rock layer two; layers one and three take stresses with a wide scatter but differently. The specific feature points to the effect rock deformation characteristics on the stress distribution within the rock mass. Hence, the calculations are adequate.

However, there is a peculiarity in the process of horizontal stress distribution when height of rocks being undermined are 0.6 and $0.7 \mathrm{~m}$. Stress growth is successive in rock layer one and in rock layers two and three maximum values are less for $0.7 \mathrm{~m}$ height of rocks being undermined to compare with $0.6 \mathrm{~m}$ height. Thus, conditions of equilibrium state of the stope roof model vary. Such a variation of maximum stress values is followed by partial transition of rock layers to their ultimate state, which results in the stope immediate roof softening under the effect of compressive horizontal stresses. 
Analysis of tensile stress graphs (Fig. 7) demonstrates a pattern being opposite to compressive stress. Changes in maximum stresses in terms of rock layers of immediate roof when height is $0.5 \mathrm{~m}$ differs greatly from options where heights of rocks being undermined are 0.6 and $0.7 \mathrm{~m}$; rock layer one is loaded more and rock layer three is loaded much less. On the whole, the calculation alternative where $0.6 \mathrm{~m}$ height of rocks being undermined is involved demonstrates indices of ultimate efficiency of immediate roof of a stope state in the context of complete backfilling. In such a case, effect by compressive stresses predominates over the effect by tensile stresses on the stability of immediate roof of a mine working.

\section{CONCLUSIONS}

Concentration of horizontal stresses, oriented along a stope face over the powered support within a stope roof is the key factor effecting a mode of progress of the main cracks within a mine working roof in the process of backfilling.

Use of complete backfilling results in the high stress concentration within an immediate roof which means its preferability in the context of high strength indices of enclosing rock mass when heights of the rocks being undermined are less than $0.6 \mathrm{~m}$.

In the context of selective coal mining, height of rocks being undermined determines the optimum parameters of a stope roof irrespective of a fine-grained rock mass in terms of the selected backfilling method.

\section{ACKNOWLEDGEMENTS}

The publication contains the results of studies conducted by Ukrainian President's grant for competitive projects F-82 "Resource-saving parameterization of the waste-free technology of backfilling the produced space in coal mines". The research is carried out within the framework of scientific topics GP-497 "Resource-saving geotechnical and hydrodynamic parametrization of the extraction of low-capacity mineral raw materials in an technogenically loaded environment", financed by the state budget of Ukraine. The authors are grateful to the mentor and teacher professor Vadym Fomychov for his support and guidance during the research.

\section{REFERENCES}

Aziz, N., \& Jalaifar, H. (2005). Experimental and numerical methodology assessment of load transfer capacity of bolts. Proceedings of the $24^{\text {th }}$ International Conference on Ground Control in Mining, 285-293.

Babets, D.V., Sdvyzhkova, O.O., Larionov, M.H., \& Tereshchuk, R.M. (2017). Estimation of rock mass stability based on probability approach and rating systems. Naukovyi Visnyk Natsionalnoho Hirnychoho Universytetu, (2), 58-64.

Bomba, A. (2018). Mathematical modelling of filtration processes in drainage systems using conformal mapping. Journal of Water and Land Development, 39(1), 11-15. https://doi.org/10.2478/jwld-2018-0054,

Bondarenko, V., Kovalevs'ka, I., \& Fomychov, V. (2012). Features of carrying out experiment using finite-element method at multivariate calculation of mine massif - combined support system. Geomechanical Processes During Underground Mining, 7-13. https://doi.org/10.1201/b13157-3
Bondarenko, V.I., Kharin, Ye.N., Antoshchenko, N.I., \& Gasyuk, R.L. (2013). Basic scientific positions of forecast of the dynamics of methane release when mining the gas bearing coal seams. Naukovyi Visnyk Natsionalnoho Hirnychoho Universytetu, (5), 24-30.

Cao, C., Nemcik, J., \& Aziz, N. (2010). Advanced numerical modeling methods of rock bolt performance in underground mines. In $10^{\text {th }}$ Underground Coal Operators' Conference (pp. 326-329). Wollongong, Australia: University of Wollongong \& the Australasian Institute of Mining and Metallurgy.

Chui, Y.V., Moshynskyi, V.S., Martyniuk, P.M., \& Stepanchenko, O.M. (2018). On conjugation conditions in the filtration problems upon existence of semipermeable inclusions. JP Journal of Heat and Mass Transfer, 15(3), 609-619. https://doi.org/10.17654/hm015030609

Dayang, X. (2013). Backfill practice in China coal mines. Journal of Mines, Metals and Fuels, (61), 225-234.

El Mkadmi, N., Aubertin, M., \& Li, L. (2014). Effect of drainage and sequential filling on the behavior of backfill in mine stopes. Canadian Geotechnical Journal, 51(1), 1-15. https://doi.org/10.1139/cgj-2012-0462

Fahey, M., Helinski, M., \& Fourie, A. (2009). Some aspects of the mechanics of arching in backfilled stopes. Canadian Geotechnical Journal, 46(11), 1322-1336. https://doi.org/10.1139/t09-063

Fan, G., Zhang, D., \& Wang, X. (2014). Reduction and utilization of coal mine waste rock in China: A case study in Tiefa coalfield. Resources, Conservation and Recycling, (83), 24-33. https://doi.org/10.1016/j.resconrec.2013.12.001

Fomichov, V., Sotskov, V. \& Malykhin, A. (2014). Determination and analysis of the acceptable benchmark changes of the stress strain state of frame and bolt fastening elements of dismantling drift when approaching a working face. Naukovyi Visnyk Natsionalnoho Hirnychoho Universytetu, (1), 22-26.

Fomichov, V., Sotskov, V., Pochepov, V., \& Mamaikin, O. (2018). Formation of a calculation model determining optimal rate of stoping face movement with a large deformation of a rock massif. ARPN Journal of Engineering and Applied Sciences, 13(7), 2381-2389.

Fomychov, V. (2012). Bases of calculation models plotting of bolt-frame support considering non-linear characteristics of physical environment behavior. Naukovyi Visnyk Natsionalnoho Hirnychoho Universytetu, (4). 54-58.

Glamheden, R., \& Hökmark, H. (2010). Creep in jointed rock masses. State of knowledge. Rune Glamheden, Golder Associates AB, Harald Hökmark, Clay Technology AB. Stockholm, Sweden: Svensk Kärnbränslehantering AB (Swedish Nuclear Fuel and Waste Management Co).

Gornostayev, S.S., Crocket, J.H., Mochalov, A.G., \& Laajoki, K.V.O. (1999). The platinum-group minerals of the Baimka placer deposits, Aluchin horst, Russian Far East. Canadian Mineralogist, 37(5), 1117-1129.

Grigoriev, O., Tereschuk, R., \& Tokar, L. (2015). Assessment of efficiency AMS-A (anchor - meshwork - shotcretihg) support structure in terms of coal mines. New Developments in Mining Engineering 2015: Theoretical and Practical Solutions of Mineral Resources Mining, 85-89. https://doi.org/10.1201/b19901-17

Haibin, L., \& Zhenling, L. (2010). Recycling utilization patterns of coal mining waste in China. Resources, Conservation and Recycling, 54(12), 1331-1340. https://doi.org/10.1016/j.resconrec.2010.05.005

Hu, F., Li, Z., Hu, R., Zhou, Y., \& Yue, R. (2018). Research on the deformation characteristics of shear band of soil-rock mixture based on large scale directs heartest. Chinese Journal of Rock Mechanics and Engineering, 37(3), 766-778.

Khalymendyk, I., \& Baryshnikov, A. (2018). The mechanism of roadway deformation in conditions of laminated rocks. Journal of Sustainable Mining, 17(2), 41-47. https://doi.org/10.1016/j.jsm.2018.03.004 
Khomenko, O.Ye., Sudakov, A.K., Malanchuk, Z.R., \& Malanchuk, Ye.Z. (2017). Principles of rock pressure energy usage during underground mining of deposits. Naukovyi Visnyk Natsionalnoho Hirnychoho Universytetu, (2), 34-43.

Kovalevs'ka, I., Symanovych, G., \& Fomychov, V. (2013). Research of stress-strain state of cracked coal-containing massif near-the-working area using finite elements technique. Annual Scientific-Technical Collection - Mining of Mineral Deposits, 159-163. https://doi.org/10.1201/b16354-28

Li, J., Nie, Y., Fu, K., Ma, C., Guo, J., \& Xu, M. (2018). Experiment and analysis of the rock breaking characteristics of disc cutter ring with small edge angle in high abrasive grounds. Journal of the Brazilian Society of Mechanical Sciences and Engineering, 40(10), 505-515. https://doi.org/10.1007/s40430-018-1422-Z

Lozynskyi, V., Saik, P., Petlovanyi, M., Sai, K., \& Malanchuk, Y. (2018). Analytical research of the stress-deformed state in the rock massif around faulting. International Journal of Engineering Research in Africa, (35), 77-88. https://doi.org/10.4028/www.scientific.net/jera.35.77

Małkowski, P., Ostrowski, Ł., \& Brodny, J. (2018). Analysis of Young's modulus for Carboniferous sedimentary rocks and its relationship with uniaxial compressive strength using different methods of modulus determination. Journal of Sustainable Mining, 17(3), 145-157.

https://doi.org/10.1016/j.jsm.2018.07.002

Malanchuk, Z.R. (2019). Substantiating parameters of zeolitesmectite puff-stone washout and migration within an extraction chamber. Naukovyi Visnyk Natsionalnoho Hirnychoho Universytetu. Preprint.

Miao, X., Zhang, J., \& Feng, M. (2008). Waste-filling in fullymechanized coal mining and its application. Journal of China University of Mining and Technology, 18(4), 479-482. https://doi.org/10.1016/s1006-1266(08)60279-5

Nehrii, S., Nehrii, T., \& Piskurska, H. (2018). Physical simulation of integrated protective structures. E3S Web of Conferences, (60), 00038. https://doi.org/10.1051/e3sconf/20186000038

Powell, J.E. (2003). Repository backfilling. Consultant's Report to Office of Nuclear Waste Isolation, 124-136.

Reynolds, J.W. (2002). Pneumatic backfilling with crushed rock at the Sullivan mine. CIM Trans, (75), 115-120.

Sdvizhkova, Ye.A., Babets, D.V., \& Smirnov, A.V. (2014). Analiz zakonomernostey formirovaniya nagruzki na krep' pri proektirovanii montazhnykh kamer strugovykh lav $\mathrm{v}$ usloviyakh shakht Zapadnogo Donbassa. Scientific Bulletin of National Mining University, (5). 26-32.
Shashenko, A., Gapieiev, S., \& Solodyankin, A. (2009). Numerical simulation of the elastic-plastic state of rock mass around horizontal workings. Archives of Mining Sciences, 54(2), 341-348

Shcherbakov, P., Tymchenko, S., Buhrym, O., \& Klymenko, D. (2019). Research into the crushing and grinding processes of iron ore with its simultaneous effect by mechanical load and electric field of ultra-high frequency. E3S Web of Conferences, (123), 01030. https://doi.org/10.1051/e3sconf/201912301030

Sotskov, V., \& Saleev, I. (2013). Investigation of the rock massif stress strain state in conditions of the drainage drift over working. Annual Scientific-Technical Collection Mining of Mineral Deposits, 197-201. https://doi.org/10.1201/b16354-36

Sotskov, V., \& Gusev, O. (2014). Features of using numerical experiment to analyze the stability of development workings. Progressive Technologies of Coal, Coalbed Methane, and Ores Mining, 401-404. https://doi.org/10.1201/b17547-68

Sotskov, V., Russkikh, V., \& Astafiev, D. (2015). Research of drainage drift during overworking of adjacent coal seam $\mathrm{C}_{5}$ under conditions of "Samarska" mine. New Developments in Mining Engineering 2015: Theoretical and Practical Solutions of Mineral Resources Mining, 221-226. https://doi.org/10.15407/mining11.01.100

Vladyko, O., Kononenko, M., \& Khomenko, O. (2012). Imitating modeling stability of mine workings. Geomechanical Processes During Underground Mining, 147-150. https://doi.org/10.1201/b13157-26

Wang, C., \& Tu, S. (2015). Selection of an appropriate mechanized mining technical process for thin coal seam mining. Mathematical Problems in Engineering, 1-10. https://doi.org/10.1155/2015/893232

Zhang, J., Zhang, Q., Huang, Y., Liu, J., Zhou, N., \& Zan, D. (2011). Strata movement controlling effect of waste and fly ash backfillings in fully mechanized coal mining with backfilling face. Mining Science and Technology, 21(5), 721-726. https://doi.org/10.1016/j.mstc.2011.03.003

Zhang, J., Jiang, H., Deng, X., \& Ju, F. (2014). Prediction of the height of the water-conducting zone above the mined panel in solid backfill mining. Mine Water and the Environment, 33(4), 317-326. https://doi.org/10.1007/s10230-014-0310-8

Zhou, N., Jiang, H.Q., \& Zhang, J.X. (2013). Application of solid backfill mining techniques for coal mine under embankment dam. Mining Technology, 122(4), 228-234. https://doi.org/10.1179/1743286313y.0000000042

\section{ДОСЛІДЖЕННЯ ТЕХНОЛОГІЧНИХ ПАРАМЕТРІВ СПОСОБУ ЧАСТКОВОГО ЗАКЛАДАННЯ ВИРОБЛЕНОГО ПРОСТОРУ ПРИ ВИКОРИСТАННІ СЕЛЕКТИВНОГО ВИЙМАННЯ ВУГІЛЛЯ}

\section{В. Соцков, Н. Деревягіна, Л. Маланчук}

Мета. Визначення факторів впливу механічних і геометричних параметрів бутових смуг, що створюються 3 присічних порід при селективному вийманні вугілля, на стан геомеханічної системи сполучення виїмкової та очисної виїмок шляхом виконання обчислювального експерименту.

Методика. Обчислювальний експеримент проведений із використанням методу скінченних елементів при моделюванні тривимірної розрахункової області геомеханічної системи. Породний масив представлений 12 шарами порід і вугільним пластом. При проведенні розрахунку сусідні породні шари вільно переміщаються відносно один одного. Розрахунок напружень та деформацій виконаний в повнорозмірному блоці $300 \times 160 \times 50$ м, який включає в себе незайманий масив, 1 очисну та 2 підготовчі виробки. Моделювання механічних характеристик бутових смуг виконано за допомогою додаткових аналітичних розрахунків.

Результати. Виконані розрахунки стану геомеханічної системи сполучень очисної та виїмкових виробок дозволили визначити характерні зони порушеного породного масиву, які визначають механізм розвитку обвалення покрівлі очисної виробки з урахуванням впливу параметрів закладки. Аналіз напружено-деформованого стану (НДС) геомеханічної системи в покрівлі очисної виробки за обраними поперечними перетинами дозволив визначити умови взаємодії породних шарів, в результаті якого відбувається опускання покрівлі на бутові смуги. 
Наукова новизна. Виявлені закономірності взаємодії покрівлі очисної виробки та елементів закладання визначають оптимальні умови управління покрівлею очисної виробки при селективному вийманні вугілля. Науково доведено, що врахування поздовжніх горизонтальних напружень для визначення оптимальних параметрів закладання дозволяє однозначно визначити тип і геометричні параметри схеми охорони виробленого простору очисної виробки при різних характеристик міцності й геометричних параметрах порушеного породного масиву.

Практична значимість. Отримані результати дозволили визначити механізм вибору швидкості посування очисного вибою, типу і геометричних параметрів бутових смуг, що споруджуються. Це дозволяє забезпечити мінімізацію витрат на внутрішню логістику видобувної дільниці, знизити собівартість очисних робіт і підвищити безпеку гірників очисного вибою.

Ключові слова: породний масив, очисна виробка, напружено-деформований стан, секція кріплення, часткове закладання, бутова смуга

\section{ИССЛЕДОВАНИЕ ТЕХНОЛОГИЧЕСКИХ ПАРАМЕТРОВ СПОСОБА ЧАСТИЧНОЙ ЗАКЛАДКИ ВЫРАБОТАННОГО ПРОСТРАНСТВА ПРИ ИСПОЛЬЗОВАНИИ СЕЛЕКТИВНОЙ ВЫЕМКИ УГЛЯ}

\section{В. Соцков, Н. Деревягина, Л. Маланчук}

Цель. Определение факторов воздействия механических и геометрических параметров бутовых полос, воздвигаемых из присекаемых пород при селективной выемке угля, на состояние геомеханической системы сопряжения выемочной и очистной выработок путем выполнения вычислительного эксперимента.

Методика. Вычислительный эксперимент проведен с использованием метода конечных элементов при моделировании трехмерной расчетной области геомеханической системы. Породный массив представлен 12 слоями пород и угольным пластом. При проведении расчета соседние породные слои свободно перемещаются относительно друг друга. Расчет напряжений и деформаций выполнен в полноразмерном блоке $300 \times 160 \times 50$ м, который включает в себя нетронутый массив, 1 очистную и 2 подготовительные выработки. Моделирование механических характеристик бутовых полос выполнено при помощи дополнительных аналитических расчетов.

Результаты. Выполненные расчеты состояние геомеханической системы сопряжений очистной и выемочной выработок позволили определить характерные зоны нарушенного породного массива, которые определяют механизм развития обрушения кровли очистной выработки с учетом влияния параметров закладки. Анализ напряженно-деформированного состояния (НДС) геомеханической системы в кровле очистной выработки по выбранным поперечным сечениям позволил определить условия взаимодействия породных слоев, в результате которого происходит опускание кровли на бутовые полосы.

Научная новизна. Выявленные закономерности взаимодействия кровли очистной выработки и элементов закладки определяют оптимальные условия управления кровлей очистной выработки при селективной выемке угля. Научно доказано, что учет продольных горизонтальных напряжений для определения оптимальных параметров закладки позволяет однозначно определить тип и геометрические параметры схемы охраны выработанного пространства очистной выработки при различных прочностных и геометрических параметрах нарушенного породного массива.

Практическая значимость. Полученные результаты позволили определить механизм выбора скорости подвигания очистного забоя, типа и геометрических параметров воздвигаемых бутовых полос. Это позволяет обеспечить минимизацию затрат на внутреннюю логистику добычного участка, снизить себестоимость очистных работ и повысить безопасность горнорабочих очистного забоя.

Ключевые слова: породный массив, очистная выработка, напряженно-деформированное состояние, секиия крепи, частичная закладка, бутовая полоса

\section{ARTICLE INFO}

Received: 6 April 2019

Accepted: 25 November 2019

Available online: 4 December 2019

\section{ABOUT AUTHORS}

Vadym Sotskov, Candidate of Technical Sciences, Associate Professor of the Department of Mining Engineering and Education, Dnipro University of Technology, 19 Yavornytskoho Ave., 49005, Dnipro, Ukraine. E-mail: vadimsockov@gmail.com

Nataliia Dereviahina, Candidate of Technical Sciences, Associate Professor of the Department of Hydrogeology and Engineering Geology, Dnipro University of Technology, 19 Yavornytskoho Ave., 49005, Dnipro, Ukraine. E-mail: natali.derev@gmail.com

Larysa Malanchuk, Candidate of Economic Sciences, Associate Professor of the Department of Public Administration, Documentation and Information Activity, National University of Water Management and Environmental Management, 11 Soborna St, 33028, Rivne, Ukraine. E-mail: 1.o.malanchuk@nuwm.edu.ua 